\title{
Pengaruh Pemberian Berbagai Macam Gula Alami Terhadap Profil Darah Dan Performans Ayam Jawa Super Fase Starter
}

\section{The Effect of Giving Various Types of Natural Sugar to Blood Profile and Performance of Super Javanese Chicken Starter Phase}

\author{
Kostomy Yusuf Prajalika ${ }^{1}$, Suhardi ${ }^{2}$, Wulandari $^{2}$ \\ ${ }^{1}$ Mahasiswa Fakultas Peternakan, Universitas Boyolali, Jl. Pandanaran No. 405 Boyolali \\ ${ }^{2}$ Dosen Fakultas Peternakan, Universitas Boyolali, Jl. Pandanaran No. 405 Boyolali \\ Tomyprajalika14@gmail.com
}

\begin{abstract}
Super Java chicken is a local Indonesian chicken whose life is closely related to the community. The purpose of this study was to determine the effect of bioavailability of natural sugar in drinking water on blood sugar levels, and performance on super stratum Javanese chickens.This study was conducted using 100 chickens divided into 4 treatments and examined for 4 days. The treatment applied is T0: administration of T1 mineral water: giving brown sugar drinking water (10\%) T2: giving sugar cane water (4.5\%) T3: giving pure honey drinking water $(7.2 \%)$. The parameters observed were ration, blood sugar, body weight, intestinal length and liver weight. Data were tested by Duncan test, to find out the differences between treatments. The real effect on feed consumption shows that the treatment of T1 with the provision of brown sugar drinking water produces the highest feed consumption of 43.10 $\mathrm{g} /$ head. The high feed consumption in T1 correlates with high body weight growth. The chicken body weight in the study was the highest, namely in the treatment of $7.2 \%$ pure honey drinking water with body weight $13.88 \mathrm{~g} /$ head. Blood sampling is done 3 times, namely at $05.00,07.00,09.00$. The highest average blood sugar level is T1 $(298,47)$. The results showed that the administration of natural sugar water in the super chicken Java starter phase did not significantly affect intestinal length and liver weight. The conclusion of this study is that the provision of brown sugar is more effective than the administration of other natural sugars.
\end{abstract}

Keywords: Java super starter phase, natural sugar, blood glucose, chicken performance

\section{PENDAHULUAN}

Ayam jawa super merupakan ayam lokal di Indonesia yang kehidupannya sudah lekat dengan masyarakat. Ayam jawa super juga dikenal dengan sebutan ayam buras (bukan ras). Penampilan ayam kampung sangat beragam, begitu pula sifat genetiknya, penyebarannya sangat luas karena populasi ayam buras dijumpai di kota maupun desa. Potensinya patut dikembangkan untuk meningkatkan gizi masyarakat dan menaikkan pendapatan keluarga.

Ayam jawa super mempunyai kelebihan pada daya adaptasi tinggi karena mampu menyesuaikan diri dengan berbagai situasi, kondisi lingkungan dan perubahan iklim serta cuaca setempat. Ayam kampung memiliki bentuk badan 
yang kompak dan susunan otot yang baik. Bentuk jari kaki tidak begitu panjang, tetapi kuat dan ramping, kukunya tajam dan kuat. Ayam kampung penyebarannya secara merata dari dataran rendah sampai dataran tinggi. Namun dikarenakan ayam jawa super ukuran tubuhnya yang cukup besar dibanding ayam kampung asli, ayam jawa super memerlukan konsumsi pakan yang tinggi. Ayam jawa super juga masih jarang ditemukan dipasaran.

Keberhasilan pemeliharaan ayam secara umum ditentukan manajemen pemeliharaan. Perlakuan DOC (Day Old Chick) pertama kali yaitu dilakukan penimbangan bobot badan sebelum masuk ke kandang brooding. Baik tidaknya performans ayam ditentukan dari bagaimana pemeliharaan di masa brooding dan fase starter. Disamping itu, faktor transportasi DOC juga mempunyai peran dalam pertumbuhan ayam tersebut.

Selama proses pengiriman DOC memungkinkan terjadinya stress dan dehidrasi atau kurang energi. Hal ini disebabkan karena DOC kehilangan sebagian cairan tubuh selama perjalanan. Dehidrasi terjadi akibat adanya perbedaan suhu hatchery dan saat pengiriman DOC. Saat tiba dikandang kebanyakan peternak memberikan air gula. Pemberian air gula ini berfungsi untuk menyuplai sumber energi mudah diserap. Selain itu, pemberian air gula ini berfungsi untuk menambah stamina ayam jawa super.

Pemberian air gula pada DOC yang pertama kali datang menjadi tradisi peternak unggas. Air gula yang biasa diberikan adalah air gula pasir. Gula pasir berasal dari ekstrak tanaman tebu. Selain air gula tebu, air gula yang ditemukan pada tanaman antara lain aren dan madu alami. Hasil tingkat konsentrasi kemanisan masing-masing gula berbeda-beda. Hal ini disebabkan karena kandungan zat gula dan ikatan karbon pada komoditas ini berbeda. Ikatan karbon ini menghasilkan kandungan energi yang berbeda pada setiap komoditasnya sehingga bioavailabilitas pada masing-masing komoditas berbeda.

Penelitian ini dilakukan dengan penggunaan gula alam berbeda tapi dengan tingkat kemanisan yang sama. Gula yang digunakan yaitu gula merah, gula tebu dan madu murni, karena gula tersebut memiliki kadar gula yang cukup tinggi dibanding sumber gula alam lainnya seperti penggunaan berbagai gula bertujuan untuk tambahan energi cepat tersedia bagi ayam karena mudah diserap, dan mengevaluasi biovailabilitas masing-masing komoditas gula. Penambahan berbagai gula alam dalam air minum pada DOC bertujuan memperbaiki pertumbuhan dan daya tahan tubuh.

Tujuan penelitian ini adalah mengetahui pengaruh bioavailabilitas pemberian gula alami pada air minum kadar gula darah, dan performans pada ayam jawa super strater. Manfaat dari penelitian ini yaitu dapat memberi informasi ilmiah kepada masyarakat tentang penggunaan larutan gula yang baik untuk ayam jawa super starter. Disamping itu, penulis dapat memberikan rujukan pada peternak mengenai gula alam yang dapat dimanfaatkan secara maksimal. 


\section{MATERI DAN METODE}

Penelitian dilaksanakan pada bulan Juli, 2018 di kandang milik Kostomy Yusuf Prajalika di Andong. Analisis bahan pakan dilakukan di Laboratorium Nutrisi dan Pakan Fakultas Peternakan Universitas Diponegoro. Analisis kandungan gula pada gula perlakuan dilakukan di Laboratorium Teknologi Pangan Fakultas Keperawatan dan Kesehatan Universitas Muhamadiyah Semarang.

\section{Materi Penelitian}

Pada penelitian ini digunakan DOC ayam jawa super yang diperoleh dari penetasan milik bapak Sulardi di Boyolali dengan jumlah 100 ekor yang dipelihara selama 4 hari. Selanjutnya dilakukan penelitian dengan 4 perlakuan yaitu dengan pemberian air minum gula alam yang berbeda. Penelitian menggunakan kandang bersekat dengan tujuan untuk mengetahui pengaruh perlakuan tersebut.

Ayam jawa super dipelihara pada kandang berukuran $400 \mathrm{~cm} \times 40 \mathrm{~cm}$. Kandang dibagi menjadi 20 petak, yang terdiri dari 5 ekor ayam / petak kandang sebagai unit percobaan. Ayam dipelihara mulai umur 1 hari sampai 4 hari dengan perlakuan yang berbeda. Masing-masing petak kandang dilengkapi dengan tempat pakan, tempat minum, dan pemanas menggunakan lampu pijar 25 watt. Peralatan yang digunakan dalam penelitian ini adalah timbangan digital merk Camry (electronic kitchen scales) yang digunakan untuk menimbang DOC, PBBH dan menimbang hati. Alat cek gula darah merk Easy Torch GCU dan stick untuk pengambilan sampel darah yang digunakan untuk mengetahui kadar gula darah setelah perlakuan.

Penelitian ini menggunakan metode percobaan Rancangan Acak Lengkap (RAL) dengan 4 perlakuan (P1, P2, P3, dan P4), dimana masing-masing perlakuan diulang 5 kali sehingga terdapat 20 unit percobaan. Pada penelitian tahap ke-1, per kotak kandang diisi 25 ekor ayam dan dibagi menjadi 5 petak tanpa membedakan jenis kelamin sehingga total ayam yang digunakan 100 ekor.

Ransum yang digunakan adalah ransum komersial BR1 starter ( $0-3$ minggu) dari PT. Japfa Comfeed. Air minum yang digunakan adalah air gula merah, air gula tebu, air madu murni dan air mineral biasa. Berdasarkan analisis kandungan nutrisi BR 1 dapat dilihat pada Tabel 1 dan kandungan gula pada Tabel 2.

Tabel 1. Kandungan nutrisi pakan BR1

\begin{tabular}{lc}
\hline \hline Nutrisi & BR 1 \\
\hline Protein kasar (\%) & 22,48 \\
Lemak Kasar (\%) & 3,22 \\
Serat kasar (\%) & 8,06 \\
Abu (\%) & 4,37 \\
Air (\%) & 10,89 \\
\hline
\end{tabular}

Sumber: Lab. Nutrisi dan Pakan Fakultas Peternakan UNDIP 
Tabel 2. Kandungan Gula

\begin{tabular}{lc}
\hline \hline Jenis Gula & Kandungan Gula (\%) \\
\hline Gula Merah & 10 \\
Gula Tebu & 22 \\
Madu murni & 14 \\
\hline
\end{tabular}

Sumber: Lab. Teknologi Pangan Fakultas Keperawatan dan Kesehatan Universitas Muhammadiyah Semarang

\section{Metode Penelitian}

Rancangan yang digunakan dalam penelitian ini adalah Rancangan Acak Lengkap (RAL). Penelitian dilakukan menggunakan rancangan acak lengkap (RAL), 4 perlakuan dengan 5 ulangan. Setiap ulangan menggunakan 5 ekor ayam umur 1 hari (DOC) ayam kampung super. Perlakuan yang diberikan berupa penambahan variasi sumber gula alam pada air minum, sebagai berikut:

T 0 = Ayam diberi ransum dan Air minum dengan air murni

T 1 = Ayam diberi ransum dan Air minum dengan air gula merah $10 \%$

T 2 = Ayam diberi ransum dan Air minum dengan air gula tebu $4,5 \%$

T 3 = Ayam diberi ransum dan Air minum dengan air madu murni 7,2\%

\section{Prosedur Percobaan}

Menyiapkan kandang 4 bok dengan masing-masing box terdiri dari 5 petak dan diisi 5 ekor DOC. Kandang berukuran panjang, lebar dan tinggi masing-masing $100 \times 40 \times 30 \mathrm{~cm}$ yang dilengkapi tempat makan dan minum serta bak tempat penampung ekskreta yang dibawahnya dilapisi lembaran plastik. Beberapa tahapan prosedur percobaan antara lain:

Penimbangan bobot awal ayam dan dimasukkan ke dalam kandang. Menyiapkan 3 jenis air gula yang akan digunakan sebagai perlakuan. Air gula diberikan dari Doc datang sampai hari ke-3. Ayam diberi pakan sesuai dengan perlakuan secara ad libitum selama kurang lebih 4 hari dan dicatat konsumsi per hari per ekor dengan menghitung pakan yang diberikan pada pagi hari dikurangi dengan pakan sisa pada sore hari. Dihitung rata-rata konsumsi harian per individu. Pada hari ke 4 dilakukan pengambilan sample darah pada setiap perlakuan, pengecekan gula darah menggunakan easy torch GCU. Pada umur 4 hari ayam dipotong, kemudian diambil organ limfoid untuk ditimbang untuk masing-masing perlakuan.

\section{Parameter Yang Diamati Konsumsi}

Konsumsi ransum konsumsi pakan diketahui dari selisih bobot badan yang diberikan dengan sisa pakan setiap hari dari masing-masing kandang ( ulangan ), selanjutnya dilakukan perhitungan. Perhitungan konsumsi pakan setiap kandang pada akhir penelitian dilakukan perhitungan konsumsi pakan kumulatif pada ulangan. Menurut Rasyaf (2011) dalam bentuk rumus dinyatakan sebagai berikut: Konsumsi pakan $=$ Jumlah pakan yang dikonsumsi - jumlah pakan yang tersisa . FCR atau sering disebut dengan Feed Consumsi Ratio dalam bahasa Indonesia adalah perbandingan antara pakan masuk dan bobot ayam. 


\section{Bobot Badan}

Data pertumbuhan bobot badan selama penelitian diperoleh dari selisih antara bobot badan akhir dengan bobot badan awal. Dengan rumus sebagai berikut (Rasyaf, 2011)

\section{Gula darah}

Pengambilan sample darah pada setiap perlakuan, pengecekan gula darah menggunakan easy torch GCU. Pengecekan dilakukan pada hari ke 4 selang 2 jam selama 6 jam.

\section{Bobot Organ Limfoid}

Persentase limfa: Perbandingan antara berat limfa dengan berat hidup dikalikan $100 \%$.

\section{Analisis Data}

Analisis data menggunakan rancangan acak lengkap dan selanjutnya dilakukan uji Duncan.

Hipotesis dari penelitian ini adalah pengaruh pemberian air gula merah dapat meningkatkan profil darah dan performans ayam jawa super fase starter.

\section{HASIL DAN PEMBAHASAN}

Hasil penelitian dengan penambahan dengan gula alami pada ayam jawa super starter disajikan pada tabel 3. Penambahan gula alami ayam jawa super fase starternya mempengaruhi konsumsi ransum dan gula darah ayam. Bobot badan, panjang usus, dan bobot hati tidak dipengaruhi oleh bahan gula alami.

Tabel 3. Rataan pada masing-masing konsumsi ransum, bobot badan, gula darah, panjang usus, dan bobot hati.

\begin{tabular}{lrrrr}
\hline \hline Perlakuan & \multicolumn{1}{c}{ T0 } & \multicolumn{1}{c}{ T1 } & \multicolumn{1}{c}{ T2 } & \multicolumn{1}{c}{ T3 } \\
\hline Konsumsi Ransum & $39.90^{\mathrm{c}}$ & $43.10^{\mathrm{a}}$ & $40.35^{\mathrm{bc}}$ & $41.90^{\mathrm{b}}$ \\
Bobot Badan & 50.52 & 53.16 & 52.60 & 54.16 \\
Gula Darah & $318.40^{\mathrm{a}}$ & $321.00^{\mathrm{a}}$ & $296.60^{\mathrm{a}}$ & $270.80^{\mathrm{b}}$ \\
Panjang Usus & 57.40 & 58.20 & 56.60 & 51.20 \\
Berat Hati & 2.34 & 2.26 & 2.06 & 1.86 \\
\hline
\end{tabular}

Keterangan: Superskrip berbeda pada setiap baris yang sama menunjukkan perbedaan nyata $(P \leq 0,05) ; T 0=$ Ayam diberi ransum dan Air minum dengan air murni; $T$ $1=$ Ayam diberi ransum dan Air minum dengan air gula merah $10 \% ; \mathrm{T} 2=$ Ayam diberi ransum dan Air minum dengan air gula tebu 4,5\%; T $3=$ Ayam diberi ransum dan Air minum dengan air madu murni 7,2\%

\section{Konsumsi Ransum}

Hasil analisis menunjukan bahwa rata-rata nilai konsumsi ransum ayam jawa super fase starter yang diberi air minum dengan penambahan sumber gula alam meningkatkan konsumsi ransum. Pengaruh nyata terhadap konsumsi pakan menunjukan bahwa pada perlakuan T1 dengan pemberian air minum gula merah menghasilkan konsumsi pakan yang paling tinggi yaitu 43,10 g/ ekor dan konsumsi 
yang terendah terdapat pada perlakuan T0 dengan pemberian air minum mineral yaitu $39,90 \mathrm{~g} /$ ekor. Tingginya konsumsi pakan pada T1 berkorelasi dengan pertumbuhan bobot badan yang tinggi. Terjadinya perbedaan konsumsi pakan pada penelitian ini disebabkan oleh perbedaan gula alam yang diberikan antara T0, T1, T2, T3.

Konsumsi ransum merupakan jumlah ransum yang dikonsumsi oleh unggas selama periode waktu tertentu dan dapat dihitung setiap hari (g/ekor/hari). Susunan ransum pada ayam jawa super sebelumnya tidak didasarkan pada standar pakan ayam jawa super karena memang standar nutrisi ayam jawa super masih belum ada. Pada penelitian ini pakan yang digunakan adalah pakan broiler padafase starter. Konsumsi yang tinggi pada perlakuan T1 (43,10 g/ekor/hari) menunjukan bahwa pada pemberian air minum gula merah sudah sesuai untuk kebutuhan ayam jawa super fase starter. Rata-rata konsumsi ransum ayam jawa super umur 1 minggu yang diberikan ransum ad libitum sebesar $42 \mathrm{~g} / \mathrm{ekor} / \mathrm{hari}$ (Ariyanti et, al. 2013). Kandunagan energi dan protein dalam ransum mempengaruhi jumlah dari konsumsi ransum ayam, hal tersebut berdampak pada pertambahan bobot badan. Gula merah mengandung sukrosa, air dan zat tak larut dalam air. Kandungan nutrisi air gula merah adalah protein, lemak, kalsium, fosfor, besi dan karbohidrat menghasilkan energi yang mampu menambah stamina pada ayam (Ariyanti et al., 2013).

\section{Bobot Badan Ayam Umur 4 Hari}

Hasil analisis menunjukan bahwa rata- rata bobot badan akhir ayam jawa super fase starter sampai hari ke - 4 nyata dipengaruhi dengan penambahan berbagai macam gula alam. Hal ini terlihat dengan meningkatkan bobot badan harian pada perlakuan T1, T2, dan T3 dibandingkan dengan perlakuan T0 sebagai kontrol. Bobot badan ayam pada penelitian yang paling tinggi yaitu pada perlakuan pemberian air minum madu murni 7,2 \% dengan bobot badan 13,88 g/ekor. Hal ini disebabkan pertambahan bobot badan sangat berhubungan dengan jumlah konsumsi ransum. Ayam mampu mengatur jumlah pasokan energy untuk memenuhi kebutuhan hidup pokok dan produksi sehingga ayam berhenti makan saat absorbs nutrient mencukupi kebutuhan. Ayam dapat mengkonsumsi ransum dengan baik dan memanfaatkan energi dari ransum untuk meningkatkan bobot badan saat kondisi ayam pada zona nyaman (Syafwan et al., 2011). Kebutuhan tubuh akan energi merupakan prioritas utama. Semua jenis karbohidrat yang dikonsumsi akan terkonversi menjadi glukosa di hati. Glukosa ini kemudian akan berperan sebagai salah satu molekul utama pembentukan energi didalam tubuh (Irawan, 2007). Pemberian air gula mengakibatkan asupan karbohidrat sebagai sumber energy mencukupi, sehingga pada tubuh ayam tidak terjadi pemecahan lemak ataupun protein.

\section{Gula Darah}

Rataan kadar glukosa darah dari masing-masing perlakuan pemberian ransum dan air minum gula alami pada ayam jawa super fase starter berkisar antara 211,60 sampai 321,00 . Pengaruh perlakuan pemberian air minum gula alami terhadap kandungan glukosa darah ayam jawa super fase starter dapat dilihat pada tabel 4 . 
Tabel 4. Kandungan glukosa darah pada perlakuan

\begin{tabular}{cllll}
\hline \hline & \multicolumn{4}{c}{ Kandungan Glukosa Darah } \\
\cline { 2 - 5 } Ulangan & \multicolumn{1}{c}{ T0 } & \multicolumn{1}{c}{ T1 } & \multicolumn{1}{c}{ T2 } \\
\hline 05.00 & $211,60^{\mathrm{b}}$ & $297,00^{\mathrm{a}}$ & $281,60^{\mathrm{a}}$ & $296,20^{\mathrm{a}}$ \\
07.00 & 216,20 & 277,40 & 230,00 & 238,80 \\
09.00 & $318,40^{\mathrm{a}}$ & $321,00^{\mathrm{a}}$ & $296,60^{\mathrm{a}}$ & $270,80^{\mathrm{b}}$ \\
\hline Total & 746,20 & 895,40 & 808,20 & 805,80 \\
\hline
\end{tabular}

Keterangan: Superskrip berbeda pada setiap baris yang sama menunjukkan perbedaan nyata $(P \leq 0,05) ; \mathrm{T} 0=$ Ayam diberi ransum dan Air minum dengan air murni; $\mathrm{T} 1$ = Ayam diberi ransum dan Air minum dengan air gula merah $10 \%$; T $2=$ Ayam diberi ransum dan Air minum dengan air gula tebu 4,5\%; T 3 = Ayam diberi ransum dan Air minum dengan air madu murni $7,2 \%$

Hasil pengecekan glukosa darah pada ayam jawa super fase starter dilakukan pada hari ke-4. Pengambilan sampel darah dilakukan 3 kali yaitu pada pukul 05.00, $07.00,09.00$. Rataan kadar gula darah tertinggi yaitu pada T1 $(298,47)$. sedangkan kadar glukosa darah pada ayam jawa super fase starter pada T0 rataan gula darah ayam berkisaran tara $(248,73-298,47)$.

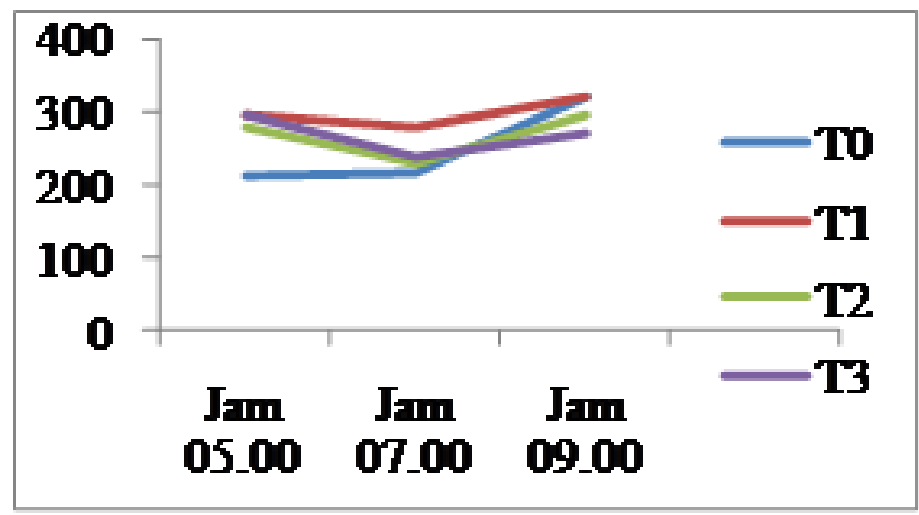

Gambar 1. Rataan kadar glukosa darah

Pengaruh perlakuan terhadap kadar gula darah ayam jawa super fase starter diketahui melalui analisis ragam. Berdasarkan hasil analisis ragam diketahui bahwa kadar gula darah pada ayam dari berbagai macam gula alam didapatkan hasil kadar gula darah yang berbeda. Kadar glukosa darah pada setiap perlakuan mengalami peningkatan yang relatif sama. Pada pukul 05.00 kadar glukosa darah pada semua perlakuan relatif tinggi, hal ini dikarenakan ayam masih diberi ransum dan air minum sesuai pada perlakuan. Setelah pukul 05.00 ayam mulai dipuasakan air minum dan diberi pakan secara ad libitum. Pada pukul 07.00 semua perlakuan mengalami homeostasis. Glukosa darah diatur agar selalu dipertahankan pada kondisi normal (sehat) dalam tubuh melalui proses homeostasis dengan bantuan hormon insulin yang disekresikan oleh kelenjar pankreas (Adisuwirjo et al., 2001).

Setelah pukul 08.00 terjadi pembongkaran adipose berjalan, hal ini dipengaruhi oleh penggunaan glukosa darah ayam. Glukosa darah ini lebih cepat 
ditranformasikan sebagai keperluan energi. Pada penelitian ini membuktikan adanya proses homeostasis yang mempertahankan kadar glukosa darah agar tetap dalam kondisi normal. Homeostasis terjadi pada saat glukosa memasuki hati. Glukosa akan langsung diserap oleh usus dan hati (Klasing , 2000).

\section{Panjang Usus}

Hasil penelitian menunjukkan bahwa pemberian air gula alami pada ayam jawa super fase starter tidak berpengaruh nyata terhadap panjang usus. Usus adalah bagian tubuh pada ternak yang berfungsi sebagai tempat terjadinya proses pencernaan makanan. Peran usus halus adalah menyerap kandungan nutrisi dalam bagian akhirnya adalah usus besar dan anus berfungsi sebagai alat ekskresi (Rasyaf, 2002). Hasil penelitian dapat dilihat dengan jumlah rataan keseluruhan panjang usus ayam jawa super fase starter dengan panjang 55, $85 \mathrm{~cm}$.

Rataan perlakuan tertinggi terletak pada perlakuan T1 yaitu dengan perlakuan pemberian ransum dan air minum gula merah $10 \%$ dengan panjang 58, $20 \mathrm{~cm}$. Rataan perlakuan terendah terdapat pada perlakuan T3 yaitu dengan perlakuan pemberian ransum dan air minum madu murni 7,2 \% dengan panjang usus 51,20 $\mathrm{cm}$. Hal ini menunjukkan bahwa pemberian air gula merah mampu meningkatkan konsumsi makanan pada ayam jawa super dibandingkan dengan gula tebu dan madu murni. Menurut Karno Suharjo (1981) tujuan pemberian gula merah adalah untuk menambah sumber nutrisi / sumber energy untuk DOC melalui air minum agar mudah diserap dan stamina ayam dapat meningkat. Jika konsumsi pakan meningkat maka panjang usus halus mengalami perluasan permukaan karena kinerja usus akan mengalami peningkatan pada proses absorbsi nutrisi pada pakan. Renodian (2001) menyatakan bahwa ransum yang memerlukan penyerapan secara intensif maka usus akan memperluas permukaannya dengan mempertebal dinding usus atau memperpanjang usus sehingga banyak nutrisi yang diserap oleh usus.

\section{Bobot Hati}

Hasil analisis menunjukan bahwa rata-rata berat hati ayam jawa super starter berat tertinggi pada perlakuan T0 yaitu perlakuan pemberian ransum dan minum air mineral atau sebagai control dengan berat hati 2,34 gram. Rataan perlakuan terendah terdapat pada perlakuan T3 yaitu dengan perlakuan pemberian ransum dan air minum madu murni 7,2 \% dengan berat hati 1,86 gram. Berat hati dipengaruhi oleh metabolisme tubuh yaitu metabolisme karbohidrat, lemak dan protein. Fungsi hati dalam metabolisme karbohidrat adalah menyimpan glikogen dalam jumlah besar, mengkonversi galaktosa dan fruktosa menjadi glukosa, glukoneogenesis, dan membentuk banyak senyawa kimia yang penting dari hasil perantara metabolisme (Guyton, 2008). Bobot hati tertinggi pada T0. Hal ini dimungkinkan adanya kinerja lebih tinggi dalam pemecahan /metabolisme gula. Kinerja metabolisme yang lebih tinggi ini bertujuan supaya menjaga kadar glukosa darah maksimal / stabil. 


\section{KESIMPULAN DAN SARAN}

\section{Kesimpulan}

Dari hasil penelitian ini maka dapat disimpulkan bahwa pemberian gula merah pada ayam jawa super fase starter lebih efektif dibandingkan pemberian gula alami yang lain, karena kandungan gula merah menghasilkan energi yang mampu menambah stamina pada ayam. Pengaruh nyata terhadap konsumsi pakan menunjukan bahwa pada pemberian air minum gula merah menghasilkan konsumsi pakan yang paling tinggi.

\section{Saran}

Agar dapat memperbaiki pertumbuhan dan daya hidup ayam jawa super fase starter sebaiknya diberikan gula merah yang merupakan sumber tambahan energi cepat tersedia bagi ayam karena mudah diserap. Perlu dilakukan penelitian lanjut untuk menghitung kebutuhan energi pada ayam jawa super fase starter.

\section{DATAR PUSTAKA}

Adisuwirjo, D. Sutrisno dan S.J.A. Setyawati. 2001. Dasar Fisiologi Ternak. Fakultas Peternakan. Universitas Jenderal Soedirman. Purwokerto.

Ariyanti, N. 2013. Penggunaan Pakan Fungsional Terhadap Daya Ikat Air, Susut Masak, dan Keempukan Daging Ayam Broiler. Jurnal Ilmu Peternakan Vol. 1 (1):10-19

Guyton, A.C. 2008. Buku Ajar Fisiologi Kedokteran Edisi 11. EGC, Jakarta.

Klasing, K. C. ; Thacker, P. ; Lopez, M. A. ; Calvert, C. C., 2000. Increasing the calcium content of mealworms (Tenebrio molitor) to improve their nutritional value for bone mineralization of growing chicks. J. Zoo Wildlife Med., 31 (4): 512-517

Rasyaf, M. 2006. Beternak Ayam Pedaging. Penebar Swadaya, Jakarta.

Renodian, D. S. 2001. Analisis Kadar, Daya Cerna dan Karakteristik Protein Daging Ayam Kampung dan Hasil Olahannya. Skripsi. Fakultas Peternakan, Institut Pertanian Bogor

Renodiati, D. 2001. Analisis kadar, Daya Cerna dan Karakteristik Protein Daging Ayam Kampung dan Hasil Olahannya. Skripsi. Program Studi Teknologi Hasil Ternak, Fakultas peternakan. Institut Pertanian Bogor

Syafwan. 2011. Konsumsi ransum, pertambahan bobot dan konversi ransum ayam lokal di Jimmy's Farm Cipanas Kabupaten Cianjur. Fakultas Peternakan. Universitas Padjajaran. 